\title{
PENGARUH KUALITAS PELAYANAN TERHADAP KEPUASAN NASABAH PADA BANK SYARIAH MANDIRI CABANG PADANGSIDIMPUAN
}

\author{
IRSAN ANDRI SIREGAR \\ PT. BPR SYARIAH OLOAN UMMAH SIDEMPUAN \\ Jalan SM. Raja No. 142 C Sitamiang, 22721 \\ Email : irsanandri26@yahoo.com
}

\begin{abstract}
ABSTRAK
Untuk meningkatkan kepercayaan nasabah dalam menggunakan jasa-jasa bank ataupun menyimpan uangnya maka bank perlu untuk menjaga citra positif di mata masyarakat. Citra ini dapat di bangun melalui kualitas produk, kualitas pelayanan dan kualitas keamanan dan kenyamanan. Tanpa citra yang positif maka kepercayaan yang sedang dan akan dibangun tidak akan efektif. Pada tanggal 12 juni 2013 PT. Bank syariah Mandiri memperoleh penghargaan dari Majalah Bloomberg Businessweek Indonesia bekerjasama dengan Frontier Consulting Group sebagai Corporate Image Award. Begitu juga terjadi di PT. Bank Syariah Mandiri Cabang Padangsidimpuan. Karena itu perlu dilihat pengaruh kualitas pelayanan terhadap kepuasan nasabahn, dengan melakukan penel;itian kuantitatif deskriftif. Adapun hasilnya menunjukkan nasabah sangat puas $81,5 \%$ nasabah puas terhadap pelayanan di Bank Syariah mandiri cabang padangsidimpuan.
\end{abstract}

\section{Kata Kunci: kualitas, pelayanan, kepuasan.}

\section{ABSTRAK}

To increase customer confidence in using bank services or to save money, the bank needs to maintain a positive image in the eyes of the public. This image can be built through product quality, service quality and quality of safety and comfort. Without a positive image, the trust that is and will be built will not be effective. On June 12, 2013 PT. Bank Syariah Mandiri received an award from Bloomberg Businessweek Indonesia Magazine in collaboration with Frontier Consulting Group as a Corporate Image Award. So also happened at PT. Bank Syariah Mandiri Branch Padangsidimpuan. Therefore, it is necessary to see the influence of service quality on customer satisfaction, by conducting quantitative descriptive research. The results show that customers are very satisfied $81.5 \%$ of customers are satisfied with the service at the Mandiri Bank Syariah branch in the vicinity of the meeting.

Keyword: quality, service, satisfaction. 


\section{PENDAHULUAN}

Bank adalah badan usaha yang menghimpun dana dari masyarakat dalam bentuk simpanan dan menyalurkannya kepada masyarakat dalam bentuk kredit atau pembiayaan serta jasa-jasa lainnya dalam rangka meningkatkan taraf hidup masyarakat. Bank salah satu lembaga keuangan yang bergerak dibidang jasa, harus dapat memberikan pelayanan yang terbaik (service excellent) untuk dapat memenangkan persaingan yang semakin hari semakin kompetitif. Service excelent adalah pelayanan yang diberikan oleh perusahaan dalam upaya untuk memberikan kepuasan dan menumbuhkan kepercayaan pihak pelanggannya (Rosa i Ruslan, 2015). Untuk itu bank harus dapat menjaga kepercayaan yang diberikan oleh nasabahnya.

Dalam dunia modern sekarang, peranan perbankan dalam memajukan perekonomian suatu negara sangatlah besar. Hampir semua sektor yang berhubungan dengan berbagai kegiatan keuangan selalu membutuhkan jasa bank. Saat ini dan masa yang akan datang masyarakat tidak akan dapat lepas dari dunia perbankan. Begitu pentingnya dunia perbankan, sehingga ada anggapan bahwa bank merupakan "nyawa” untuk menggerakkan roda perekonomian suatu Negara (Kasmir, 2008).

Untuk meningkatkan kepercayaan nasabahnya dalam menggunakan jasajasa bank ataupun menyimpan uangnya maka bank perlu untuk menjaga citra positif di mata masyarakat. Citra ini dapat di bangun melalui kualitas produk, kualitas pelayanan dan kualitas keamanan dan kenyamanan. Tanpa citra yang positif maka kepercayaan yang sedang dan akan dibangun tidak akan efektif (Kasmir, 2014).

Dalam dunia perbankan yang semakin berkembang pesat dengan meningkatnya intensitas persaingan dan jumlah pesaing, menuntut setiap bank untuk selalu memperhatikan kebutuhan dan keinginan para nasabahnya serta berusaha memenuhi harapan para nasabahnya dengan cara memberikan pelayanan yang lebih memuaskan daripada yang dilakukan oleh bank lain.

Bank juga salah satu yang bergerak di bidang bisnis yang tentunya salah satu tujuannnya adalah untuk menciptakan para pelanggan yang puas. Kualitas jasa yang unggul dan konsisten dapat menumbuhkan kepuasan pelanggan dan akan memberikan berbagai manfaat. Di saat bank syariah muncul, persaingan 
semakin ketat, baik secara nasional maupun internasional. Dalam kondisi seperti ini para bankir berusaha keras untuk memenuhi kebutuhan dan keinginan nasabah yakni salah satunya dengan cara memberikan pelayanan yang prima.

Pelayanan yang cepat dan efisien dapat menciptakan hubungan yang berkesinambungan antara nasabah dengan pihak bank sedangkan complain dan membiarkan nasabah menunggu berlama-lama dalam transaksi bisnis atau mencairkan uangnya, mengabaikan teknologi pelayanan, bahkan masih ada kalau nasabah ingin kreditnya lancar, nasabah harus tahu persis selera petugas pelayanan dan direksi bank. Dalam surat An-Nisa' ayat 29, Allah menegaskan:

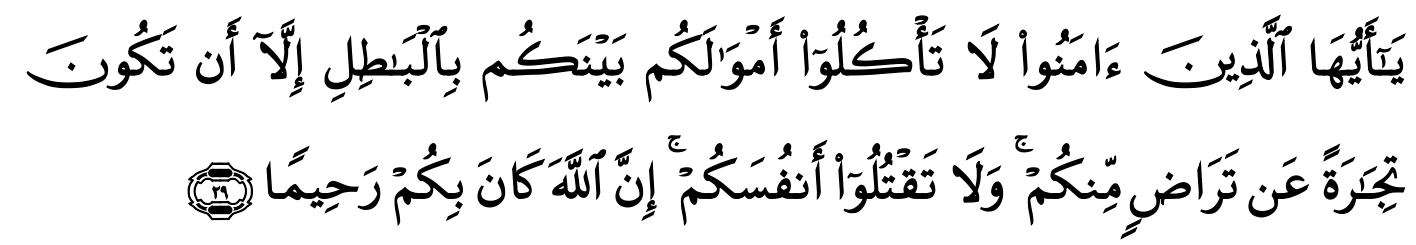

Artinya: "Hai orang-orang yang beriman, janganlah kamu saling memakan harta sesamamu dengan jalan yang batil, kecuali dengan jalan perniagaan yang Berlaku dengan suka sama-suka di antara kamu. Dan janganlah kamu membunuh dirimu. Sesungguhnya Allah adalah Maha Penyayang kepadamu”.

Ayat tersebut menjelaskan mengharuskan menciptakan, menjaga, dan meningkatkan kepuasan pelanggan. Ini mengisyaratkan bahwa seberat apapun tingkat kompetisi yang dihadapi, bisnis perbakan tetap akan mendatangkan keuntungan yang baik, halal, dan barakah, sepanjang pihak perbankan Islam dapat meningkatkan kepuasan nasabahnya.

Kualitas dan kepuasan nasabah sangat berkaitan, kualitas memberikan suatu dorongan kepada nasabah untuk menjalin ikatan yang kuat dengan bank. Ikatan yang seperti ini dalam jangka panjang memungkinkan bank untuk memahami dengan seksama harapan nasabah serta kebutuhan mereka.

Bank yang gagal memuaskan nasabahnya melalui pelayanannya akan menghadapi masalah yang kompleks, masalah tersebut diantaranya adalah jika nasabah tidak merasa tidak puas dengan pelayanan bank tersebut maka akan menyampaikan ketidak puasannnya kepada orang lain. Dan bisa dibayangkan betapa besarnya kerugian dari kegagalan memuaskan nasabah. Oleh karena itu, setiap bank wajib merencanakan, mengorganisasikan, mengimplementasikan, 
dan mengendalikan sistem pengendalian kualitas pelayanan sedemikian rupa, sehingga pelayanan dapat memuaskan para nasabahnya (Philip kotler, 2002).

Pada tanggal 12 juni 2013 PT. Bank syariah Mandiri memperoleh penghargaan dari Majalah Bloomberg Businessweek Indonesia bekerjasama dengan Frontier Consulting Group sebagai Corporate Image Award dan masih banyak lagi penghargaan-penghargaan yang diterima oleh PT. Bank Syariah Mandiri tentang kualitas pelayanan.

Demikian juga terjadi di PT. Bank Syariah Mandiri Cabang Padangsidimpuan sebagai tempat penelitian ini. Upaya peningkatan kualitas pelayanan oleh Bank Syariah Mandiri Cabang Padangsidimpuan selalu berusaha untuk menemukan langkah-langkah yang berorientasi pada kepuasan nasabah. Namun masih muncul pertanyaan, apakah hal tersebut telah benar-benar dapat memberikan kepuasan bagi nasabah Bank Syariah Mandiri Cabang Padangsidimpuan bila dilihat dari dari lima dimensi pelayanan.

Bank Syariah Mandiri Cabang Padangsidimpuan perlu mengidentifikasi apakah pelayanan yang selama ini diberikan telah sesuai dengan harapan nasabah. Hal ini sebagai bukti perhatian Bank Syariah Mandiri Cabang Padangsidimpuan terhadap kepuasan nasabahnya. Apabila harapan nasabah lebih besar dari tingkat layanan yang diterima, maka nasabah tidak puas. Dan apabila harapan nasabah sama/ lebih kecil dari tingkat layanan yang diterima, maka tidak akan puas.

Sebagai salah satu usaha untuk mempertahankan nasabah, Bank Syariah Mandiri Cabang Padangsidimpuan harus dapat memilih mana bentuk kebijakan maupun teknologi yang paling tepat yang harus digunakan untuk mencapai tujuan yang ditetapkan. Hal tersebut akan mempengaruhi ketepatan, keakuratan, kemampuan dan kecepatan bank dalam memerikan pelayanan kepada nasabah. Dengan demikian dapat disimpulkan bahwa salah satu faktor yang dapat mendongkrak bangsa pasar suatu bank adalah kualitas pelayanan.

\section{LANDASAN TEORI}

\section{Pengertian Kualitas Pelayanan}

kualitas adalah keseluruhan dari kelengkapan fitur suatu produk atau jasa yang tergantung pada kemampuannya untuk memuaskan kebutuhan yang dinyatakan atau tersirat (Rambat Lupiyoadi, 2009). Pelayanan adalah tindakan 
atau perbuatan seseorang atau organisasi untuk memberikan kepuasan kepada nasabah. Tindakan tersebut dapat dilakukan melalui cara langsung melayani nasabah (Kasmir, 2004).

Dalam praktiknya, nasabah yang membutuhkan sesuatu yang perlu pelayanan sesuai dengan keinginannya dibagi menjadi empat macam yaitu:

Pertama, nasabah sangat perlu bantuan seseorang petugas pelayanan untuk menuntun atau memperoleh informasi tentang segala sesuatu yang berhubungan dengan produk, mulai dari mencari produk yang diinginkan, memilih produk, meminta penjelasan tentang produk sampai dengan pembayaran kepada Teller. Rentetan pelayanan ini merupakan kesatuan yang tidak dapat dipisah-pisahkan satu sama lainnya. Pelayanan seperti ini biasanya diberikan untuk produk yang belum begitu dikenal oleh produk baru.

Kedua, nasabah memerlukan bantuan hanya seperlunya saja, artinya nasabah datang kemudian mencari sendiri, memilih sendiri baru terakhir berhubungan dengan petugas yang bersangkutan.

Ketiga, nasabah membutuhkan bantuan tetapi melalui telepon. Jadi dalam hal ini nasabah tidak berhubungan langsung dengan secara fisik dengan petugas pelayanan. Bantuan lewat telepon yang dapat diberikan miasalnya informasi seputar produk, keluhan nasabah.

Keempat, asabah tidak memerlukan bantuan banker kecuali dalam keadaan darurat, seperti dalam penggunaan mesin ATM dan kartu nasabah tertelan oleh mesin ATM. Walaupun demikian, untuk pelayanan jenis ini juga harus dijaga supaya jangan sampai terjadi masalah dengan nasabah yaitu salah satunya dengan mengontrol kualitas mesin yang digunakan. Seorang petugas banker dituntut untuk memberikan pelayanan yang prima kepada nasabahnya.

\section{Mengukur Kualitas Pelayanan}

Ada lima dimensi pokok kualitas pelayanan antara lain:

Satu, Kehandalan (Reliability)

Merupakan kemampuan perusahaan menyampaikan jasa yang akurat dan konsisten. Dalam al-Qur'an juga diterangkan mengenai pelaksanaan janji yang telah disepakati yaitu dalam Q.S Al-Mukminun ayat: 8 


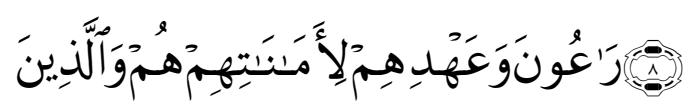

Artinya: "dan orang-orang yang memelihara amanat-amanat (yang dipikulnya) dan janjinya." (Q.S Al-Mukminun:8)

Dua, Daya Tanggap (Responsiveness)

Merupakan kemauan untuk memberikan pelayanan dan membantu nasabah dengan segera. Apabila perusahaan tidak menepati komitmen dalam memberikan pelayanan yang baik, maka resiko yang akan terjadi adalah ditinggalkan oleh pelanggan. Lebih dari itu Allah Swt berfirman dalam Q.S AlMaidah ayat: 1

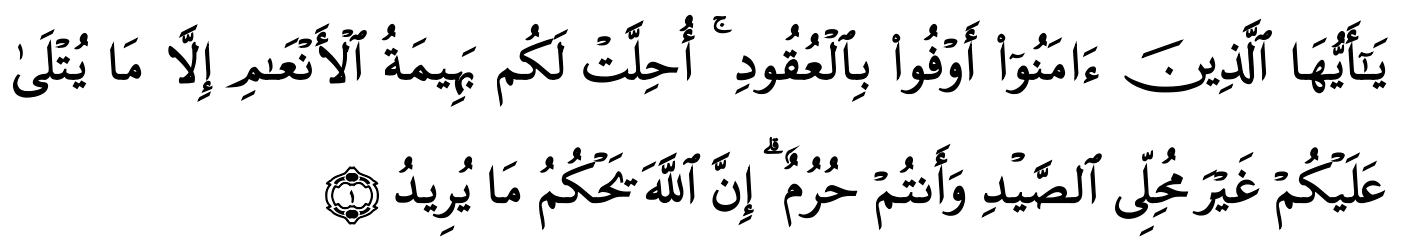

Artinya: "Hai orang-orang yang beriman, penuhilah aqad-aqad itu. Dihalalkan bagimu binatang ternak, kecuali yang akan dibacakan kepadamu. (yang demikian itu) dengan tidak menghalalkan berburu ketika kamu sedang mengerjakan haji. Sesungguhnya Allah menetapkan hukumhukum menurut yang dikehendaki-Nya".

Tiga, Jaminan (Assurance)

Adalah kompetensi, sopan santun, kredibilitas, dan keamanan yang akan membantu keyakinan nasabah bahwa ia akan mendapatkan jasa yang diharapkan. Hal ini sejalan dengan Q.S Ali Imran ayat 159

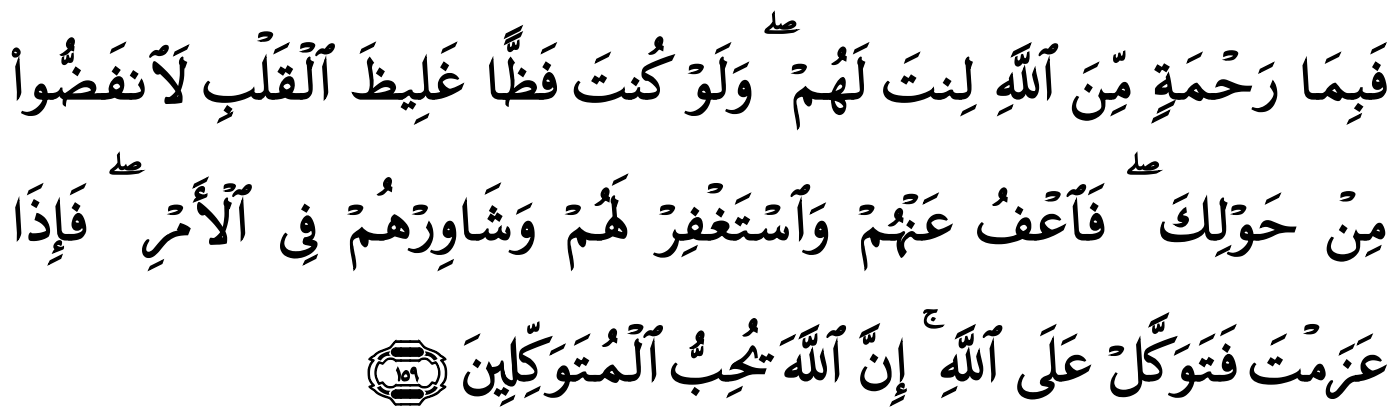

Artinya: "Maka disebabkan rahmat dari Allah-lah kamu Berlaku lemah lembut terhadap mereka. Sekiranya kamu bersikap keras lagi berhati kasar, tentulah mereka menjauhkan diri dari sekelilingmu.karena itu ma'afkanlah mereka, mohonkanlah ampun bagi mereka, dan bermusyawaratlah dengan mereka dalam urusan itu.Kemudian 
apabila kamu telah membulatkan tekad, Maka bertawakkallah kepada Allah.Sesungguhnya Allah menyukai orang-orang yang bertawakkal kepada-Nya”. (Q.S Ali Imran:159)

Empat, Empati (Emphaty)

Meliputi kemudahan dalam melakukan hubungan dengan konsumen, komunikasi yang baik, perhatian dan memahami pelanggan. Perhatian yang diberikan oleh perusahaan kepada konsumen haruslah dilandasi dengan aspek keimanan dalam rangka mengikuti seruan Allah Swt untuk selalu berbuat baik kepada orang lain sesuai dengan firman Allah dalam Q.S An-Nahl ayat 90:

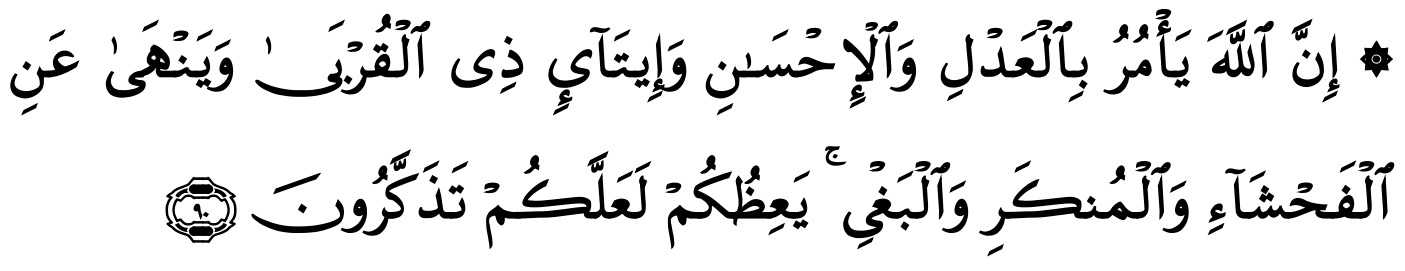

Artinya: "Sesungguhnya Allah menyuruh (kamu) Berlaku adil dan berbuat kebajikan, memberi kepada kaum kerabat, dan Allah melarang dari perbuatan keji, kemungkaran dan permusuhan. Dia memberi pengajaran kepadamu agar kamu dapat mengambil pelajaran”. Q.S An-Nahl ayat 9o:

Lima, Sarana Fisik (Tangible)

Dimensi ini merupakan aspek perusahaan jasa yang mudah terlihat dan ditemui nasabah (Fandi Tjiptono, 2002) yaitu kualitas. Kualitas memberikan suatu dorongan kepada pelanggan untuk menjalin ikatan hubungan yang kuat dengan perusahaan. Perusahaan dapat meningkatkan kepuasan pelanggan dimana perusahaan memaksimumkan pengalaman pelanggan yang menyenangkan dan meminimumkan pengalaman pelanggan yang kurang menyenangkan (Fandi Tjiptono, 2002).

\section{METODE PENELITIAN}

Penelitian ini dilakukan dengan metode kuantitatif diskriptif. Yang menjadi populasinya seluruh nasabah yang yang ada di Bank Syariah Mandiri cabang Padangsidimpuan berjumlah \pm 1.200 orang, dan ditetapkan sampelnya 120 orang, dengan berpedoman kepada pendapat Suharsimi Arikunto yang mengatakan apabila populasi lebih dari 100 dapat diambil antara 10-15 \% atau 
20-25\% atau lebih (Suharsimi Arikunto, 2009). Teknik pengumpulan datanya dengan metode dokumentasi dan angket. Sedangkan analisis datanya dengan uji validitas, reliabilitas dan Uji t.

\section{HASIL PENELITIAN}

Pada variabel kualitas pelayanan (X) yang menjadi uji coba sebanyak 30 orang diluar dari uji sampel sebanyak 120 orang. Item pertanyaannya sebanyak 25 hal ini dapat dilihat dari hasil rekapitulasi sebagai berikut:

Hasil Rekapitulasi Uji Validitas Instrumen Angket Terhadap Variabel Kualitas Pelayanan (X)

\begin{tabular}{|c|c|c|c|c|}
\hline $\begin{array}{c}\text { No item } \\
\text { pertanyaan }\end{array}$ & $\begin{array}{c}\text { Koefisien } \\
\text { Korelasi } \\
\left(\mathrm{r}_{\text {hitung }}\right)\end{array}$ & $\begin{array}{l}\text { Nilai } \\
\text { thitung }\end{array}$ & Nilai tabel & Interpretasi \\
\hline 1 & 0,512 & 3,153 & \multirow{25}{*}{$\begin{array}{l}\text { Instrumen valid } \\
\text { jika, } \mathrm{t}_{\text {hitung }}>\mathrm{t}_{\text {tabel }} \\
(1,701) \text { dan } \mathrm{n}=30\end{array}$} & Valid \\
\hline 2 & 0,762 & 6,221 & & Valid \\
\hline 3 & 0,518 & 3,205 & & Valid \\
\hline 4 & 0,531 & 3,316 & & Valid \\
\hline 5 & 0,502 & 3,074 & & Valid \\
\hline 6 & 0,575 & 3,719 & & Valid \\
\hline 7 & 0,469 & 2,810 & & Valid \\
\hline 8 & 0,436 & 2,562 & & Valid \\
\hline 9 & 0,498 & 3,038 & & Valid \\
\hline 10 & 0,578 & 3,748 & & Valid \\
\hline 11 & 0,667 & 4,737 & & Valid \\
\hline 12 & 0,356 & 2,016 & & Valid \\
\hline 13 & 0,155 & 0,831 & & Tidak Valid \\
\hline 14 & 0,161 & 0,862 & & Tidak Valid \\
\hline 15 & 0,463 & 2,764 & & Valid \\
\hline 16 & 0,304 & 1,689 & & Tidak Valid \\
\hline 17 & 0,402 & 2,323 & & Valid \\
\hline 18 & 0,504 & 3,089 & & Valid \\
\hline 19 & 0,386 & 2,212 & & Valid \\
\hline 20 & 0,525 & 3,263 & & Valid \\
\hline 21 & 0,720 & 5,489 & & Valid \\
\hline 22 & 0,576 & 3,730 & & Valid \\
\hline 23 & 0,118 & 0,628 & & Tidak Valid \\
\hline 24 & 0,523 & 3,248 & & Valid \\
\hline 25 & 0,031 & 0,164 & & Tidak Valid \\
\hline
\end{tabular}

Dari hasil tabel rekapitulasi di atas 20 item pertanyaan yang valid, dan 5 pertanyaan tidak valid. 
Pada variabel kepuasan nasabah (Y) yang menjadi uji coba sebanyak 30 orang diluar dari uji sampel sebanyak 120 orang. Item pertanyaannya sebanyak 5 hal ini dapat dilihat dari hasil rekapitulasi sebagai berikut:

Hasil Rekapitulasi Uji Validitas Instrumen Angket Terhadap Variabel Kepuasan Nasabah (Y)

\begin{tabular}{|c|c|c|c|c|}
\hline $\begin{array}{c}\text { No item } \\
\text { pertanyaan }\end{array}$ & $\begin{array}{c}\text { Koefisien } \\
\text { Korelasi } \\
\left(\text { r }_{\text {hitung }}\right)\end{array}$ & $\begin{array}{l}\text { Nilai } \\
\text { thitung }\end{array}$ & Nilai tabel & Interpretasi \\
\hline 1 & 0,625 & 4,236 & \multirow{5}{*}{$\begin{array}{l}\text { Instrumen valid } \\
\text { jika, thitung }>t_{\text {tabel }} \\
(1,701) \text { dan } n=30\end{array}$} & Valid \\
\hline 2 & 0,658 & 4,623 & & Valid \\
\hline 3 & 0,498 & 3,039 & & Valid \\
\hline 4 & 0,510 & 3,137 & & Valid \\
\hline 5 & 0,704 & 5,245 & & Valid \\
\hline
\end{tabular}

Dari hasil tabel rekapitulasi di atas 5 item pertanyaan semua valid.

Hasil Rekapitulasi Uji Reliabilitas Instrumen Angket Terhadap Variabel Kualitas Pelayanan (X)

\begin{tabular}{|c|c|c|c|c|}
\hline $\begin{array}{c}\text { No item } \\
\text { pertanyaan }\end{array}$ & $\begin{array}{c}\text { Koefisien } \\
\text { Korelasi } \\
\left(\mathrm{r}_{\text {hitung }}\right)\end{array}$ & Nilai $r_{11}$ & Nilai $r_{\text {tabel }}$ & Interpretasi \\
\hline 1 & 0,512 & 2,098 & \multirow{23}{*}{$\begin{array}{c}\text { Instrumen valid } \\
\text { jika, } r_{11}>r_{\text {tabel }} \\
(0,374) \text { dan } n=30\end{array}$} & Reliabel \\
\hline 2 & 0,762 & 0,865 & & Reliabel \\
\hline 3 & 0,518 & 0,683 & & Reliabel \\
\hline 4 & 0,531 & 0,694 & & Reliabel \\
\hline 5 & 0,502 & 0,668 & & Reliabel \\
\hline 6 & 0,575 & 0,730 & & Reliabel \\
\hline 7 & 0,469 & 0,639 & & Reliabel \\
\hline 8 & 0,436 & 0,607 & & Reliabel \\
\hline 9 & 0,498 & 0,665 & & Reliabel \\
\hline 10 & 0,578 & 0,733 & & Reliabel \\
\hline 11 & 0,667 & 0,984 & & Reliabel \\
\hline 12 & 0,356 & 0,525 & & Reliabel \\
\hline 13 & 0,155 & 0,268 & & Tidak Reliabel \\
\hline 14 & 0,161 & 0,277 & & Tidak Reliabel \\
\hline 15 & 0,463 & 0,633 & & Reliabel \\
\hline 16 & 0,304 & 0,466 & & Tidak Reliabel \\
\hline 17 & 0,402 & 0,574 & & Reliabel \\
\hline 18 & 0,504 & 0,670 & & Reliabel \\
\hline 19 & 0,386 & 0,557 & & Reliabel \\
\hline 20 & 0,525 & 0,689 & & Reliabel \\
\hline 21 & 0,720 & 0,837 & & Reliabel \\
\hline 22 & 0,576 & 0,731 & & Reliabel \\
\hline 23 & 0,118 & 0,211 & & Tidak Reliabel \\
\hline
\end{tabular}




\begin{tabular}{|l|l|l|l|l|}
\hline 24 & 0,523 & 0,687 & \multirow{5}{*}{} & Reliabel \\
\hline 25 & 0,031 & 0,060 & & Tidak Reliabel \\
\hline
\end{tabular}

\section{Hasil Rekapitulasi Uji Reliabilitas Instrumen Angket Terhadap} Variabel Kepuasan Nasabah (Y)

\begin{tabular}{|c|c|c|c|c|}
\hline $\begin{array}{c}\text { No item } \\
\text { pertanyaan }\end{array}$ & $\begin{array}{c}\text { Koefisien } \\
\text { Korelasi } \\
\left(\mathrm{r}_{\text {hitung }}\right)\end{array}$ & Nilai $r_{11}$ & Nilai $r_{\text {tabel }}$ & Interpretasi \\
\hline 1 & 0,625 & 0,769 & \multirow{5}{*}{$\begin{array}{l}\text { Instrumen valid } \\
\text { jika, } r_{11}>r_{\text {tabel }} \\
(0,374) \text { dan } n=30\end{array}$} & Reliabel \\
\hline 2 & 0,658 & 0,794 & & Reliabel \\
\hline 3 & 0,498 & 0,665 & & Reliabel \\
\hline 4 & 0,510 & 0,676 & & Reliabel \\
\hline 5 & 0,704 & 0,826 & & Reliabel \\
\hline
\end{tabular}

Hasil uji reliabilitas dalam tabel di atas menunjukkan bahwa nilai alpha dari dimensi servqual adalah : 9,366 (tangibles), 1,1587(reliability), 1,801(responsiveness), 2,257 (assurance) dan 0,7966(empathy) sedangkan untuk kepuasan nasabah adalah 0,687. Jadi secara keseluruhan butir-butir yang ada dalam masing-masing variabel adalah reliabel (andal) karena lebih besar dari $r$ tabel. Jadi, secara keseluruhan pertanyaan dari tiap-tiap variabel dapat digunakan dan dapat didistribusikan kepada seluruh responden (120 orang), karena tiap-tiap butir menunjukkan hasil yang valid dan reliabel.

Variabel Kualitas Pelayanan (X)

Distribusi Frekuensi Variabel X

(Kualitas Pelayanan)

\begin{tabular}{|c|c|c|}
\hline Interval Kelas & Frekuensi & Persentasi \\
\hline $84-86$ & 7 & $6 \%$ \\
\hline $81-83$ & 13 & $11 \%$ \\
\hline $78-80$ & 39 & $33 \%$ \\
\hline $75-77$ & 33 & $27 \%$ \\
\hline $72-74$ & 18 & $15 \%$ \\
\hline $69-71$ & 6 & $5 \%$ \\
\hline $66-68$ & 3 & $2 \%$ \\
\hline $63-65$ & 1 & $1 \%$ \\
\hline Jumlah & 120 & $100 \%$ \\
\hline
\end{tabular}


Berdasarkan tabel di atas penyebaran frekuensi variabel kualitas pelayanan menunjukkan bahwa responden yang ada pada interval 63-65 sebanyak 1 orang (1\%), interval 66-68 sebanyak 3 orang (2\%), Interval 69-71 sebanyak 6 orang (5\%), interval 72-74 sebanyak 18 orang (15\%), interval 75-77 sebanyak 33 orang (27\%), interval 78-80 sebanyak 39 orang (33\%), interval 81-83 sebanyak 13 orang (11\%) dan interval 84-86 sebanyak 7 orang (6\%).

Untuk mengetahui berapa besar skor kualitas pelayanan secara komulatif seperti data berikut:

$$
a=\text { JumlahSkorKriteria } \times \text { JumlahItem } \times \text { JumlahResponden } \quad(5 \times 20 \times
$$
$120=12000$ ). Dengan demikian kualitas pelayanan menurut 120 orang (studi kasus pada PT Bank Syariah Mandiri Padangsidimpuan) yaitu

$$
=\frac{\text { jumlahskorpengumpulandata }}{a} \times 100 \%=\left(\frac{9234}{12000} \times 100 \%\right)=76,95 \%
$$

Dari kriteria yang ditetapkan dapat diinterpretasikan skor 76,95\% berada pada interval daerah "baik".

Dari perhitungan di atas dapat diperoleh skor pengaruh kualitas pelayanan adalah 76,95\%. Berdasarkan kriteria interprestasi skor, maka skor $76 \%$ berada pada taraf $61-80 \%$ yang berarti baik.

Variabel Kepuasan Nasabah (Y)

Distribusi Frekuensi Variabel Y (Kepuasan Nasabah)

\begin{tabular}{|c|c|c|}
\hline Interval Nilai & Frekuensi & Persentasi \\
\hline $24-25$ & 16 & $13 \%$ \\
\hline $22-23$ & 15 & $12 \%$ \\
\hline $20-21$ & 43 & $36 \%$ \\
\hline $18-19$ & 37 & $31 \%$ \\
\hline $16-17$ & 9 & $8 \%$ \\
\hline Jumlah & 120 & $100 \%$ \\
\hline
\end{tabular}

Berdasarkan table penyebaran frekuensi variabel kepuasan nasabah menunjukkan responden yang ada pada interval 16-17 sebanyak 9 orang (8\%), interval 18-19 sebanyak 37 orang (31\%), Interval 20-21 sebanyak 43 orang (36\%), interval 22-23 sebanyak 15 orang (12\%), dan interval 24-25 sebanyak 16 orang $(13 \%)$. 
Tampilan diagram batang penyebaran skor responden dapat dilihat di bawah ini:

Untuk mengetahui berapa besar skor kepuasan nasabah secara komulatif seperti data berikut:

$a=$ Jumlah Skor Kriteria $\times$ Jumlah Item $\times$ Jumlah Responden $\quad(5 \times 5 \times$ $120=3000$ ). Dengan demikian kepuasan nasabah menurut 120 orang (studi kasus pada PT Bank Syariah Mandiri Padangsidimpuan) yaitu :

$$
=\frac{\text { jumlahskorpengumpulandata }}{a} \times 100 \%=\left(\frac{2445}{3000} \times 100 \%\right)=81,5 \%
$$

Dari perhitungan di atas dapat diperoleh skor kepuasan nasabah adalah $81,5 \%$. Berdasarkan kriteria interprestasi skor, maka skor $81 \%$ berada pada taraf 81-100\% yang berarti sangat baik.

a. Menghitung harga korelasi sebagai berikut:

$$
\begin{aligned}
& r_{X Y}=\frac{n\left(\sum X Y\right)-\left(\sum X\right)\left(\sum Y\right)}{\sqrt{\left\{n \cdot \sum X^{2}-(X)^{2}\right\} \cdot\left\{n \cdot \sum Y^{2}-\left(\sum Y\right)^{2}\right\}}} \\
& r_{X Y}=\frac{120\left(\sum 188434\right)-\left(\sum 9234\right)\left(\sum 2445\right)}{\sqrt{\left\{120 \cdot \sum 712610-\left(\sum 9234\right)^{2}\right\} \cdot\left\{120 \cdot \sum 50409-\left(\sum 2445\right)^{2}\right\}}} \\
& r_{X Y}=\frac{22612080-22577130}{\sqrt{\{85513200-85266756\} \cdot\{6049080-5978025\}}} \\
& r_{X Y}=\frac{34950}{\sqrt{246444.71055}} \\
& r_{X Y}=\frac{34950}{\sqrt{17511078420}} \\
& r_{X Y}=\frac{34950}{41846,24048} \\
& r_{X Y}=0,835
\end{aligned}
$$

b. Mencari besar sumbangan (konstribusi) variabel X terhadap Y $\mathrm{KP}=\mathrm{r}^{2} \times 100 \%=0,835^{2} \times 100 \%=0,697 \times 100 \%=69,7 \%$, artinya variabel kualitas pelayanan memberikan konstribusi terhadap kepuasan nasabah (studi kasus pada PT Bank Syariah Mandiri Padangsidimpuan) sebesar 69,7\% dan sisanya 30,3\% ditentukan oleh variabel lainnya. 
c. Menguji signifikansi sebagai berikut:

$t_{\text {hitung }}=\frac{\mathrm{r} \sqrt{\mathrm{n}-2}}{\sqrt{1-\mathrm{r}^{2}}}=\frac{0,835 \sqrt{120-2}}{\sqrt{1-(0,835)^{2}}}=\frac{0,835 \sqrt{118}}{\sqrt{1-0,697225}}=\frac{0,835 \times 10,86278049}{\sqrt{0,302775}}=\frac{8,369021642}{0,550249943}$

$=\frac{9,939444149}{0,403453838}=15,1004498$ dibulatkan menjadi $t_{\text {hitung }}=15,101$

Mencari $t_{\text {tabel }}$ dengan siginfikansi $\alpha=0,05$ dan $\mathrm{dk}=\mathrm{n}-\mathrm{k}-1=102-2-1=$ 117

Maka dicari interpolasi

$\mathrm{C}=\mathrm{C}_{0}+\frac{\left(\mathrm{C}_{1}-\mathrm{C}_{0}\right)}{\left(\mathrm{B}_{1}-\mathrm{B}_{0}\right)} \cdot\left(\mathrm{B}-\mathrm{B}_{0}\right)=1,671+\frac{(1,658-1,671)}{(120-60)}=1,671+\frac{(-0,013)}{(60)}$

$=1,671-0,000216666=1,670783334$ jadi, dibulatkan menjadi $\mathrm{C}=1,671$

Jadi, $t_{\text {hitung }}(15,101)>t_{\text {tabel}}(1,671)$, maka Ho ditolak; artinya ada pengaruh yang Signifikan antara kualitas pelayanan terhadap kepuasan nasabah (studi kasus pada PT Bank Mandiri Syariah Padangsidimpuan).

d. Mencari regresi sederhana

Persamaan regresi dirumuskan, $\hat{Y}=\mathrm{a}+\mathrm{bx}=9,448+0,142$

$\mathrm{b}=\frac{\mathrm{n} \sum \mathrm{XY}-\sum \mathrm{X} \cdot \sum \mathrm{Y}}{\mathrm{n} \cdot \sum \mathrm{X}^{2}-\left(\sum \mathrm{X}\right)^{2}}=\frac{120 \sum 188434-\sum 9234 \cdot \sum 2445}{120 \cdot \sum 712610-\left(\sum 9234\right)^{2}}=\frac{22612080-22577130}{85513200-85266756}$

$\frac{34950}{246444}=0,141817208$ dibulatkan menjadi $\mathrm{b}=0,142$

$\mathrm{a}=\frac{\sum \mathrm{Y}-\mathrm{b} \cdot \sum \mathrm{X}}{\mathrm{n}}=\frac{\sum 2445-0,142 \cdot \sum 9234}{120}=\frac{\sum 2445-1311,228}{120}$

$\frac{1133,772}{120}=9,4481$ dibulatkan menjadi $\mathrm{a}=9,448$

$\bar{X}=\frac{\sum \mathrm{X}}{n}=\frac{9234}{120}=76,95$

$\bar{Y}=\frac{\sum Y}{n}=\frac{2445}{120}=20,375$ 
Garis persamaan regresi

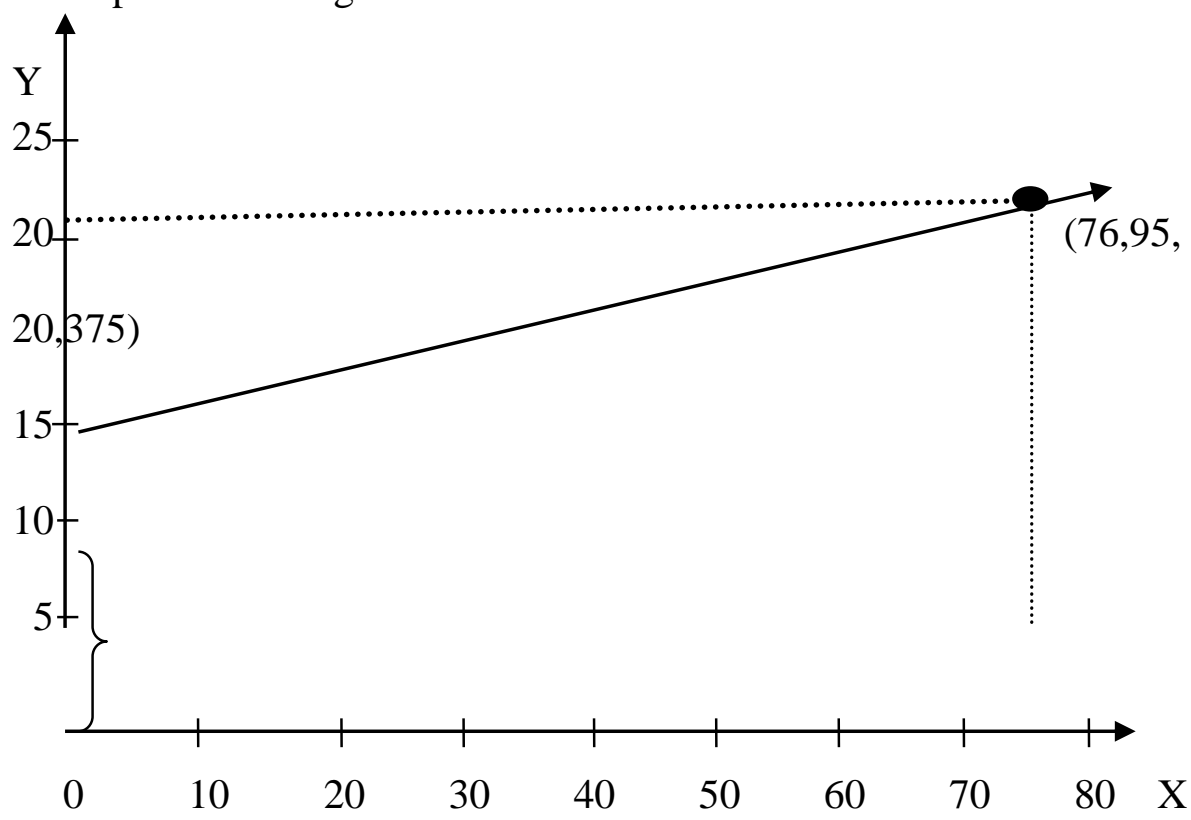

Menguji signifikansi

$$
\begin{aligned}
& \mathrm{JK}_{\operatorname{Reg}(\mathrm{a})}= \frac{\left(\sum \mathrm{Y}\right)^{2}}{\mathrm{n}}=\frac{\left(\sum 2445\right)^{2}}{120}=\frac{5978025}{120}=49816,875 \\
& \mathrm{JK}_{\operatorname{Reg}(\mathrm{b} / \mathrm{a})=} \mathrm{b} \cdot\left\{\sum \mathrm{XY}-\frac{\left(\sum \mathrm{X}\right) \cdot\left(\sum \mathrm{Y}\right)}{\mathrm{n}}\right\}=0,142 \cdot\left\{\sum 188434-\right. \\
&\left.\frac{\left(\sum 9234\right) \cdot\left(\sum 2445\right)}{120}\right\} 0,142 \cdot\left\{\sum 188434-\frac{(22577130)}{120}\right\}= \\
& 0,142 \cdot\left\{\sum 188434-188142,75\right\}=0,142 \cdot 291,25=41,3575 \\
& \text { dibulatkan menjadi JK } \operatorname{Reg(b/a)}=41,358
\end{aligned}
$$

$\mathrm{JK}_{\mathrm{Res}}=\Sigma \mathrm{Y}^{2}-\mathrm{JK}_{\mathrm{Reg}(\mathrm{b} / \mathrm{a})}-\mathrm{JK}_{\operatorname{Reg}(\mathrm{a})}=50409-41,358-49816,875=550,767$

$\mathrm{RJK}_{\operatorname{Reg}}[a]=\mathrm{JK}_{\operatorname{Reg}}[a]=49816,875$

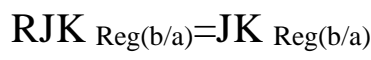

$\mathrm{RJK}_{\mathrm{Res}}=\frac{J K_{\mathrm{Res}}}{n-2}=\frac{550,767}{120-2}=\frac{550,767}{118}=4,667516949=4,668$

$\mathrm{F}_{\text {hitung }}=\frac{R J K_{\mathrm{Reg}(\mathrm{b} / \mathrm{a})}}{R J K_{\mathrm{Res}}}=\frac{41,358}{4,668}=8,859897172$, dibulatkan menjadi 8,860

Kaidah pengujian signifikansi

Jika $F_{\text {hitung }} \geq \mathrm{F}_{\text {tabel }}$ maka tolak Ho artinya signifikan dan

$$
F_{\text {hitung }} \leq \mathrm{F}_{\text {tabel }} \text { maka terima Ho artinya tidak signifikan }
$$

Dengan taraf signifikansi $\alpha=0,01$ atau 0,05 


$$
\begin{aligned}
& \begin{aligned}
& \mathrm{F}_{\text {tabel }}= \mathrm{F}\{(1-\alpha)(d k \operatorname{Reg}((\mathrm{b} \mid \mathrm{a})) \cdot(\mathrm{dkRes})\} \\
&= \mathrm{F}\{(1-0,05)(d k \operatorname{Reg}((\mathrm{b} \mid \mathrm{a})=1) \cdot(\mathrm{dkRes}=120-2)\} \\
&= \mathrm{F}(0,95)(1,118) \\
& \mathrm{F}_{\text {tabel }} \quad: \text { Angka } 1 \quad=\text { pembilang } \\
& \quad \text { Angka } 118=\text { penyebut }
\end{aligned} \\
& \mathrm{F}_{\text {tabel }}=\text { tidak tercantum dalam tabel } \\
& \text { Maka dicari interpolasi } \\
& \mathrm{C}=\mathrm{C}_{0}+\frac{\left(\mathrm{C}_{1}-\mathrm{C}_{0}\right)}{\left(\mathrm{B}_{1}-\mathrm{B}_{0}\right)} \cdot\left(\mathrm{B}-\mathrm{B}_{0}\right)=3,91+\frac{(3,89-3,91)}{(200-150)}=3,91+\frac{(-0,02)}{(50)} \\
& =3,91-0,0004=3,9096 \text { jadi, dibulatkan menjadi } \mathrm{C}=3,910 \\
& \mathrm{~F}_{\text {tabel }}=3,910
\end{aligned}
$$

Dengan demikian $F_{\text {hitung }}>F_{\text {tabel }}(8,860>3,910)=$ maka tolak Ho artinya signifikan, terdapat pengaruh yang signifikan antara kualitas pelayanan terhadap kepuasan nasabah.

\section{DAFTAR PUSTAKA}

Kasmir, Dasar-Dasar Perbankan, Jakarta, PT. Raja Grafindo, Persada, 2008

Kasmir, Manajemen Perbankan, Jakarta, PT. Raja Grafindo, 2004

Philip kotler, Manajemen Pemasaran, Jakarta, Prenhallindo, 1997

Philip Kotler, Manajemen Pemasaran, Jakarta Indeks, 2007

Rambat Lupiyoadi, Manajemen Pemasaran Jasa, Jakarta, Salemba Empat, 2009

Rosad i Ruslan, Manajemen Public Relations dan Median Komunikasi, Jakarta, PT. Raja Grafindo, 2005

Tim Redaksi, Kamus Besar Bahasa Indonesia Edisi Ketiga, Jakarta, Balai Pustaka, 2001

Fandi Tjiptono, Management Service, Yogyakarta : Andi, 2008

Fandi Tjiptono, Strategi Pemasaran, Yogyakarta, Edisi Kedua, Andi, 2002 